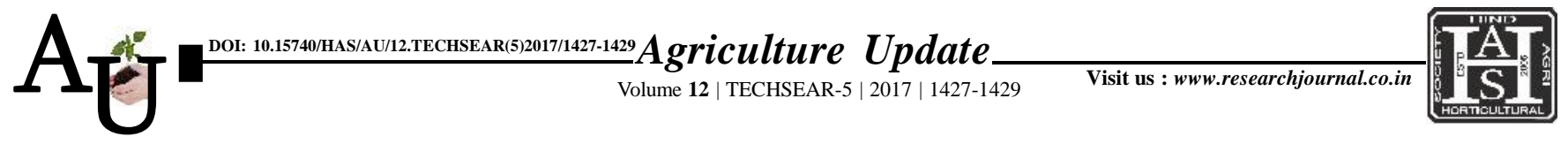

\title{
Rеsearch автісle: Constraints in marketing vegetables and suggestions as perceived by growers for improving vegetable marketing
}

\section{B. GOPI CHAND, P.K. BANERJEE AND SRIKANTH BANDI}

Article Chronicle: Received : 15.07.2017;

Accepted : 30.07.2017

KEY Words:

Constraints, Marketing vegetables, Prices, Market intelligence

Author for correspondence :

\section{B. GOPI CHAND}

Department of

Extension Education,

Orissa University of

Agriculture and

Technology,

BHUBANESWAR (ODISHA)

INDIA

Email : gopichandbalusu

@ gmail.com

See end of the article for authors' affiliations
SUMMARY : The present study conducted to study the constraints faced by vegetable growers in marketing their produce in the khammam district of Telangana. Both purposive and random sampling followed for a total sample size of one hundred and twenty. The respondent indicated lack of market information, inadequate physical facilities in the market, fluctuation in market price, lack of reasonable support prices as their major problems in marketing vegetables. They suggested to provide regular information on market prices, increase in number of rythubazar (direct market), display of prices at each market place and fixing minimum price for the produce based on production cost. Market intelligence is inevitable in the daily fluctuating prices and a perfect model developed to disseminate information through smart technology. Enhancement in the delivery of government extension agencies to win the trust of the farmers.

How to cite this article : Chand, B. Gopi, Banerjee, P.K. and Bandi, Srikanth (2017). Constraints in marketing vegetables and suggestions as perceived by growers for improving vegetable marketing. Agric. Update, 12(TECHSEAR-5) : 1427-1429; DOI: 10.15740/HAS/AU/12.TECHSEAR(5)2017/1427-1429. 